\title{
Laparoscopy or laparotomy for high risk caesarean scar pregnancy?a retrospective study
}

\author{
Ronghua Liu ${ }^{1}$, Ting Zhou ${ }^{1}$, Pengfei $\mathrm{Cui}^{1}$, wenwen wang ${ }^{1}$, and SHIXUAN WANG ${ }^{1}$ \\ ${ }^{1}$ Tongji Hospital of Tongji Medical College of Huazhong University of Science and \\ Technology
}

May 29, 2020

\begin{abstract}
Objective The aim of this study was to compare the outcomes of with laparotomy or laparoscopy in the treatment of high-risk CSP and evalute the optimal treatment measure about it. Design A retrospective study. Setting Tongji Hospital. Population 278 patients with caesarean scar pregnancy between 2013 and 2018. Methods We compared and analysed the characteristics of the laparoscopic and open surgeries in the treatment of high-risk CSP and the advantages and disadvantages of different methods of vascular pretreatment. We also systematically evaluated CSP patients undergoing laparoscopic or laparotomic surgery. Results Intraoperative bleeding, transfusion rate, total days of hospitalization and postoperative hospital stay were better in laparoscopy than in laparotomy $(\mathrm{p}<0.05)$. There was no difference in the factors $(\beta$-HCG decrease, reoperation and tissue residues $)$ closely related to the success of the surgery in the two groups. Furthermore, we pretreated blood vessels differently before the operation. Tissue residue, reoperation and intraoperative blood transfusion rates in patients with temporary vascular occlusion were better than in patients with permanent vascular occlusion. As of the latest English literature, the systematic review results showed that most of the current studies on CSP are case reports and retrospective analyses (67.74\% and 29.03\%, respectively), and the sample sizes of these retrospective studies are very small. Conclusions This study revealed that laparoscopic surgery is superior to laparotomic surgery in the treatment of high-risk CSP. Patients benefited from temporary arterial occlusion in both groups. Temporary arterial occlusion under laparoscopic surgery may be the best treatment for high-risk CSP.
\end{abstract}

\section{Hosted file}

manuscript . doc available at https : //authorea.com/users/327614/articles/455098-laparoscopy-orlaparotomy-for-high-risk-caesarean-scar-pregnancy-a-retrospective-study

\section{Hosted file}

Table 1.docx available at https://authorea.com/users/327614/articles/455098-laparoscopy-orlaparotomy-for-high-risk-caesarean-scar-pregnancy-a-retrospective-study

\section{Hosted file}

Table 2.docx available at https://authorea.com/users/327614/articles/455098-laparoscopy-orlaparotomy-for-high-risk-caesarean-scar-pregnancy-a-retrospective-study

\section{Hosted file}

Table 3.docx available at https://authorea.com/users/327614/articles/455098-laparoscopy-orlaparotomy-for-high-risk-caesarean-scar-pregnancy-a-retrospective-study

\section{Hosted file}


Table 4.docx available at https://authorea.com/users/327614/articles/455098-laparoscopy-orlaparotomy-for-high-risk-caesarean-scar-pregnancy-a-retrospective-study

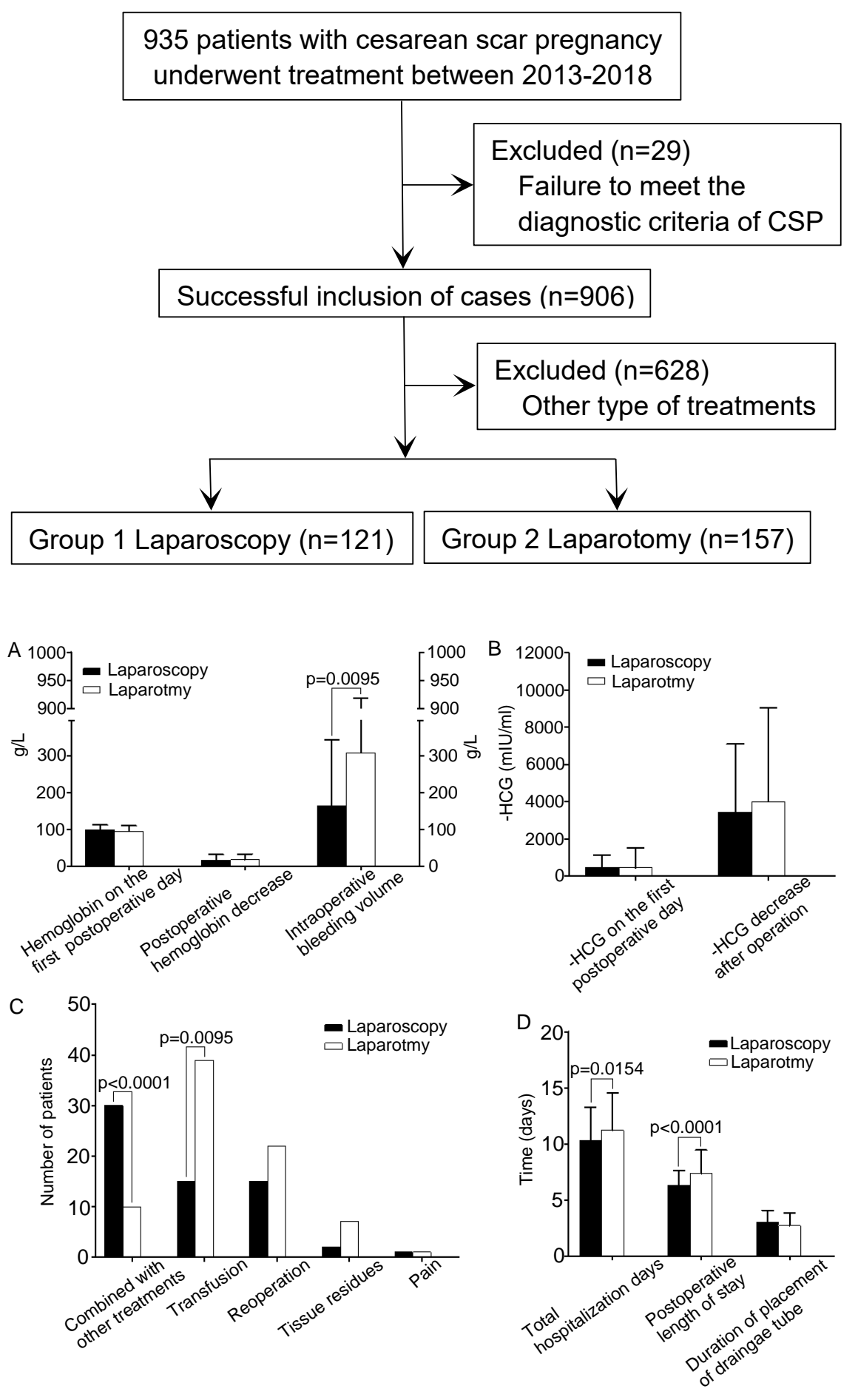



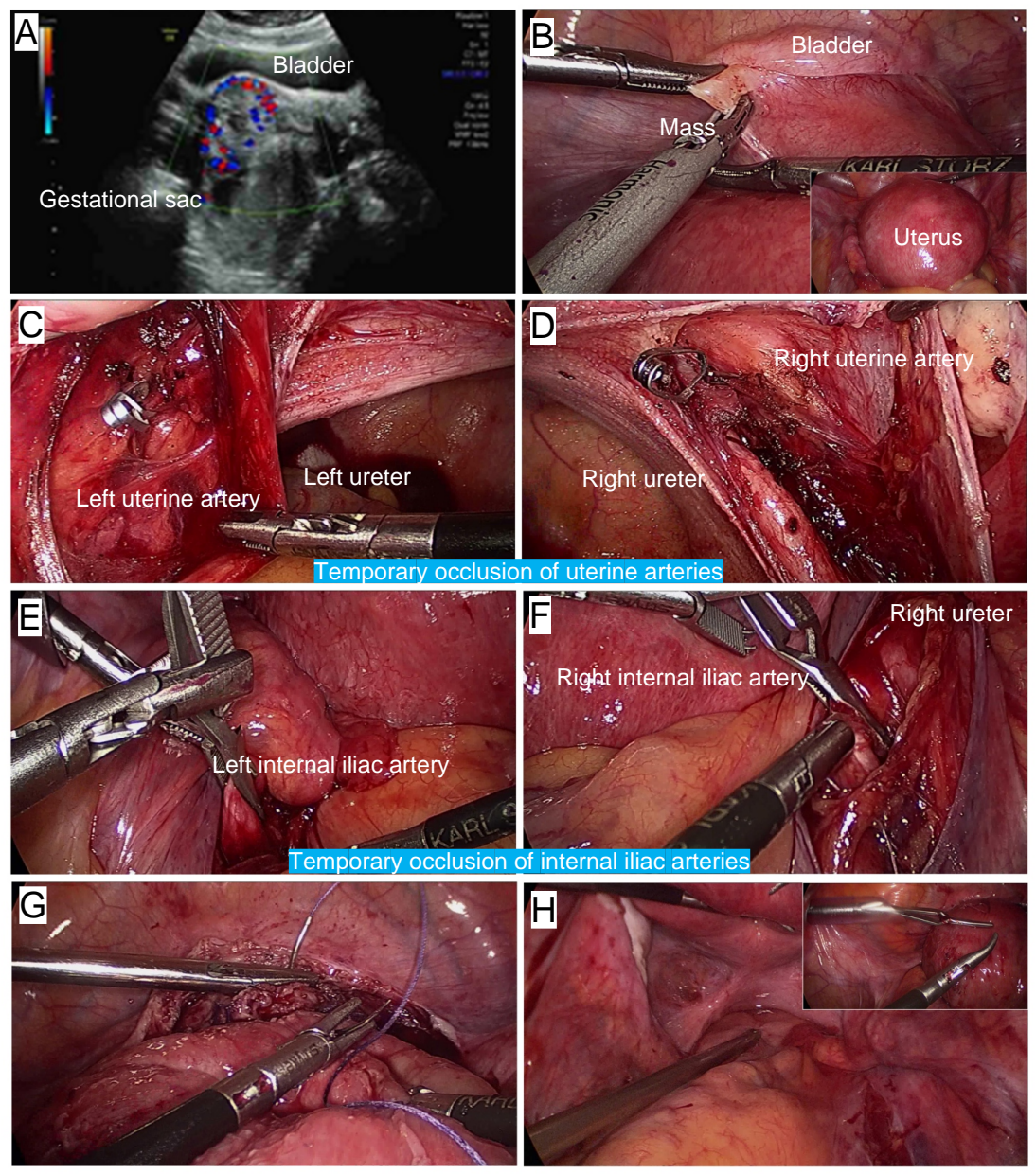